Ayurlog: National Journal of Research in Ayurved Science

\title{
To evaluate the effect of loha content ayurvedic remedies to increase hemoglobin percentage in iron deficiency anaemia
}

\author{
Milind G. Rajguru \\ Ph.D. Scholar, Tilak Maharashtra Vidyapeeth Pune, \\ Assistant Professor, Kayachikitsa Dept., V.P.A.M.C. Sangli, Maharashtra, India \\ *Corresponding author: milind_rajguru@yahoo.com
}

\begin{abstract}
Iron deficiency anaemia ${ }^{1}$ is the common disease now a days. It occurs in higher and middle economic classes because of their fast and mechanical life style, fast food habits and less nutritional vegetable because of used fertilizers an preservatives and in poor class due to malnutrition. Doctors prescribed hematinic medicine for those patients for increase their haemoglobin. Ayurvedic Vaidyas also used the same medicine in Pandu. But in Ayurveda many loha kalpas are prescribed under vyadhi Pandu and are effective for curing the disease. So the aim of this study was to assess the efficacy of Loha contained ayurvedic remedies to increase haemoglobin percentage in the patients of Iron deficiency Anaemia.
\end{abstract}

Key words: Loha contained ayurvedic remedies, Iron deficiency anaemia, Haemoglobin, Pandu

\section{Introduction:}

Ayurvedic idea of Pandu is centered around 'Vaivarnya' or 'off colour'. Pandu means fading of the original colour ${ }^{2}$. Many people tend to believe that anaemia means podern condition of Pandu. Many ymptoms described in modern medicine for anaemia match with the Ayurvedic concept of Pandu. Anaemia is a condition in which the amount of haemoglobin is $\operatorname{low}^{3}$.

The latest survey in 2016 showed that nearly $48 \%$ of women in our country are anaemic and this figure in men is $24 \%$ (National Family Health Survey) In Maharashtra the percentage of anaemic adolescent girls is much higher than the all India figure of $56 \%$. The survey was conducted on over 9.9 crore girls in the state. The report stated that given the condition of the girls, susceptible to many infections and diseases. Experts said the 
findings were of concern as anaemic girls being undernourished were the first to drop out of school and were married off early. The survey conducted by National Family Health Survey (NFHS) 2015-2016 declared anaemia among all women in Maharashtra is $48 \%{ }^{4}$ and Global Data epidemiologist analyses the prevalence of anaemia in India is $39.86 \%(2017)$.This condition occurs due to poor eating habits that is not eating enough fruits, vitamin $\mathrm{C}$, legumes such as pod, peas beans etc. The consumption of a wide variety of nutritious foods is important for women's health. Adequate amounts of protein, fat, carbohydrates, vitamins, and minerals are required for a well balanced diet.

Now a day there are many modern medicines in the market for increase haemoglobin percentage in anaemia patients. Many Ayurvedic Vaidayas also prescribed same modern medicine for the treatment of pandu. There are many ayuevedic remedies described in Ayurvedic Samhitas for the treatment of pandu. But there were questions of effectiveness of ayurvedic drugs to increase the Haemoglobin percentage in anaemic patients

\section{AIM AND OBJECTIVES}

To assess the efficacy of Loha content ayurvedic remedies to increase haemoglobin percentage in the patients of Iron deficiency Anaemia.

\section{MATERIALS AND METHOD}

\section{Source}

Patients who were fulfilling the sign and symptoms of Anaemia were selected from OPD in Kayachikitsa department at Vasantdada Patil Ayurvedic Medical College Sangli.

\section{INCLUSION CRITERIA:}

1. Patients suffering from Iron deficiency Anaemia in between 18 to 60 years of age.

2. Patients having Anaemia laxanas.

3. Haemoglobin levels not less than 6 $\mathrm{g} / \mathrm{dl}$

4. No other symptoms like high grade fever, infections etc.

5. Sex was no bar for inclusion.

\section{EXCLUSION CRITERIA:}

1. Patients suffering from severe anaemia ( $\mathrm{Hb}$ below $6 \mathrm{~g} / \mathrm{dl})$

2. Other types of anaemias viz. Thalacemia, Sickle cell anaemia, anaemia due to malaria, bleeding piles etc.

3. Communicable diseases like TB, HIV etc. 
4. Patients suffering from haemorrhagic disorders like Arsha, Raktapitta.

5. Patients having severe dehydration.

6. Patients suffering from Prameha, Hridrogas.

7. Patients having HIV +ve and cancer of any type.

\section{Material used}

Loha contained ayurvedic medicine which are given regularly in OPD/IPD in Vasantdada Patil Ayurvedic Medical College Sangli

1. Lohasava $20 \mathrm{ml}$ two times after meal with water

2. saptamruta loha vati 500mg times after meal with water
3. Navayasa loha churna $500 \mathrm{mg}$ two times after meal with goghrit

4. Tapyadi loha vati $500 \mathrm{mg}$ two times after meal with water

5. Nisha loha vati $500 \mathrm{mg}$ two times after meal with water

Duration of treatment -One month (30 days)

\section{METHODOLOGY}

70 patients were selected for the study who fulfilling above criteria. Haemoglobin percentage checked before the treatment and above loha kalpa was given as per above duration, dose and anupana. In this period patients asked to eat his/her routine diet and after the treatment Haemoglobin percentage checked again.

OBSEVATION AND RESULT

Analysis of haemoglobin percentage before and after treatment

\begin{tabular}{|l|l|l|l|l|l|l|}
\hline \multicolumn{1}{|c|}{ HB\% } & $\mathbf{N}$ & \multicolumn{1}{|c|}{$\begin{array}{c}\text { Minimum } \\
\text { HB\% }\end{array}$} & $\begin{array}{c}\text { Maximum } \\
\text { HB\% }\end{array}$ & Mean & Std. Error & Std.Deviation \\
\hline $\begin{array}{l}\text { Before } \\
\text { treatment }\end{array}$ & 70 & 6.0 & 13.2 & 9.839 & 0.2111 & 1.7664 \\
\hline $\begin{array}{l}\text { After } \\
\text { treatment }\end{array}$ & 70 & 7.3 & 13.9 & 10.651 & 0.2031 & 1.6996 \\
\hline
\end{tabular}

\section{DISCUSSION:}

Mean score of hemoglobin percentage before treatment was 9.83 and after treatment it increase up to 10.65 i.e. average haemoglobin percentage increase up to 0.82 $\mathrm{gm} / \mathrm{dl}$ in seven weeks of treatment and is statistically significant.

CONCLUSION: Loha content remedies is useful ayurvedic treatment for curing iron deficiency anaemia and for increase haemoglobin percentage

\section{REFERENCES:}

1. Davidson's Principles and Practice of Medicine C.R.W. Edwards and others Seventeenth Edition P.N.783-586

2. Charak samhita Charak chandrika of Dr Bramhanand Tripathi, edited by Dr. Prabhakar Janardan Deshpande, Chaukhamba surbharti 
prakashana, Chikitsa sthanam

Pandurog chikitsa Hindi

commentary Pg 590

3. Overview of Anaemia,Merck Manual-Consumer Versionwww.merckmanual.com
4. World Class Parasites Vol. 2 by Celiav V. Holland, Malcolm W. Kennedy pg 47

\section{Cite article:}

To evaluate the effect of loha content ayurvedic remedies to increase hemoglobin percentage in iron deficiency anaemia

Milind G. Rajguru

Ayurlog: National Journal of Research in Ayurved Science- 2019; (7)(1): 1-4 